\title{
Synergistic Effect of Chloroquine and Copper to the Euryhaline Rotifer Proales Similis
}

\section{Uriel Arreguin Rebolledo}

Universidad Nacional Autonoma de Mexico https://orcid.org/0000-0001-9232-531X

\section{Roberto Rico-Martínez}

Universidad Autónoma de Aguascalientes

\section{Rocío Fernández}

Universidad Nacional Autónoma de México

Federico Páez-Osuna ( $\square$ paezos@ola.icmyl.unam.mx)

Universidad Nacional Autónoma de México

\section{Research Article}

Keywords: Emerging pollutants, COVID-19, Chemical mixtures, Synergistic effect, Aquatic invertebrates, Aquatic toxicology

Posted Date: August 31st, 2021

DOI: https://doi.org/10.21203/rs.3.rs-824455/v1

License: (9) This work is licensed under a Creative Commons Attribution 4.0 International License. Read Full License

Version of Record: A version of this preprint was published at Ecotoxicology on August 1st, 2022. See the published version at https://doi.org/10.1007/s10646-022-02570-2. 


\section{Abstract}

Chloroquine (CQ) has been widely used for many years against malaria and various viral diseases. Its important use and high potential to being persistent make it of particular concern for ecotoxicological studies. Here, we evaluated the toxicity of $\mathrm{CQ}$ alone and in combination with copper $(\mathrm{Cu})$ to the euryhaline rotifer Proales similis. All experiments were carried out using chronic toxicity reproductive five-day tests and an application factor (AF) of $0.05,0.1,0.3$ and 0.5 by multiplying the $24-h L^{2} C_{50}$ values of CQ (4250 $\mu \mathrm{g} / \mathrm{L})$ and $\mathrm{Cu}(68 \mu \mathrm{g} / \mathrm{L})$. The rate of population increase $\left(r, \mathrm{~d}^{-1}\right)$ ranged from 0.50 to 52 (controls); 0.19 to 0.39 (CQ); 0.09 to 0.42 (Cu); and -0.03 to 0.29 (CQ-Cu) and decreased significantly as the concentration of both chemicals in the medium increased. Almost all tested mixtures induced synergistic effects, mainly as the AF increased. We found that the presence of $\mathrm{Cu}$ intensifies the vulnerability of organisms to CQ and vice versa. These results stress the potential hazard that these combined chemicals may have on the aquatic systems. This research suggests that $P$. similis is sensitive to CQ as other standardized zooplankton species and may serve as a potential test species in the risk assessment of emerging pollutants in marine environments.

\section{Introduction}

Emerging pollutants (EPs) are becoming more common in nature. This is a general term that primarily refers to the compounds that have the potential to enter the environment and are still largely unregulated by existing water quality regulations (Wells et al., 2010). These human-made chemicals include personal care products, pesticides, nanoparticles, microplastic and pharmaceuticals demanded by modern society (Gavrilescu et al., 2015; Egbuna et al., 2021). There are growing concerns regarding the global production of synthetic chemicals. In recent years, 400 million tons per year have been produced, and at least $50 \%$ are environmentally harmful chemicals (Gavrilescu et al., 2015). Additionally, human needs could increase EPs' demand in the contemporary world (Bunke et al., 2019).

Pharmaceuticals, including antibiotics, antidiabetic, antiepileptics, antimalarial, analgesics and antiinflammatories, are frequently reported in freshwater and marine environments (Gavrilescu et al., 2015; Gu and Wang, 2015). Many of these drugs are not biodegraded during the wastewater treatment and are discharged in an active form to aquatic environments (Fang et al., 2012; Liu et al., 2020). Consequently, they are regularly detected in levels ranging from $\mathrm{ng} / \mathrm{L}$ to $\mathrm{mg} / \mathrm{L}$. The bioavailability of pharmaceutical drugs in aquatic ecosystems has a significant ecological effect on the aquatic biota. For instance, in primary consumers such as rotifers and cladocerans, these compounds negatively affect their biological parameters (life span, reproductive rates, generation time, and population increase) (Varano et al., 2017; González-Pérez et al., 2018). On the other hand, pharmaceuticals can alter the behaviour traits of secondary consumers (fishes) and affects their ecological interaction (Brodin et al., 2014). It is documented that pharmaceutical drugs accumulate and biomagnify in the tissues of animals through the food chain (Zenker et al., 2014). Finally, they cause a decrease in the abundance and diversity of aquatic invertebrate communities (Ali et al., 2021). Despite the evident risk, pharmaceuticals are still 
necessary to address the current adversities, as exemplified by the COVID-19 (Coronavirus Disease 2019) pandemic (Espejo et al., 2020).

Chloroquine is an antimalarial treatment utilized for more than seven decades, given that it is a safe drug that is easy to obtain at a relatively low cost (Attia et al., 2021). It is a drug repurposing successfully used to treat various diseases in humans comprising $\mathrm{VIH}, \mathrm{Q}$ fever, influenza $\mathrm{H} 5 \mathrm{~N} 1$, malaria, hepatitis $\mathrm{C}$, dengue virus, zika virus, and chikungunya virus. Furthermore, it has been tested in cancer patients with promising results (Yan et al., 2013; Plantone and Koudriavtseva, 2018). From this perspective, CQ is considered a drug with current and future potential applications. Chloroquine was one of the first drugs suggested for treating coronavirus disease 2019 (COVID-19) (Colson et al., 2020). Despite limited evidence, it was very early (March 2019) announced as a promising drug candidate against COVID-19; this led to a huge demand for and substantial use of this drug (Roustit et al., 2020). Later (June 2020), it was suspended due to their safety concerns reported by researchers (WHO, 2020).

In the COVID-19 scenario, a CQ dose of 500 to $1000 \mathrm{mg} /$ day for seven days was recommended (Pastick et al., 2020). For other diseases such as malaria and chikungunya virus, CQ is administered in $10-25$ $\mathrm{mg} / \mathrm{kg}$ and $250 \mathrm{mg}$ daily, respectively (Taylor and White, 2004; Delogu and de Lamballerie, 2011). Approximately $50 \%$ of those amounts are excreted unchanged in the urine and feces; hence, substantial amounts of these wastes enter the aquatic environment due to inadequate treatment of residual waters (Kuroda et al., 2021). Chloroquine has a long half-life in both the human body and the environment (Olatunde et al., 2014; Kuroda et al., 2021). Because of their potential to be a persistent pollutant in water, some mechanisms for CQ degradation have been proposed, but at present, they are not implemented worldwide (Midassi et al., 2020).

Copper $(\mathrm{Cu})$ is ubiquitous in the environment and are thus frequently in marine environments. The US Environmental Protection Agency has listed it as one of the priority contaminants. Cu bioavailability in the aquatic environment may be natural or influenced by anthropogenic (mining, metallurgic industry, aquaculture, agriculture, etc.) sources (Páez-Osuna and Osuna-Martínez, 2015). Cu is an essential trace element for many physiological functions (e.g., mitochondrial respiration, normal cell growth and development and antioxidant defence). However, it can be harmful to human health and aquatic life at high concentrations (Ansari et al., 2003). There is growing concerned about the toxicity of copper to aquatic invertebrates, including marine zooplankton, since this metal's presence in the medium, even at low concentrations $(10-50 \mu \mathrm{g} / \mathrm{L})$, adversely affects the population dynamics, which translates into potential risks to the trophic structure of aquatic ecosystems (Schuler et al., 2008; Kwok et al., 2008; Bao et al., 2013; Rebolledo et al., 2021). In some cases, this risk intensifies when $\mathrm{Cu}$ is combined with other toxic substances (Bao et al., 2014; Jia et al., 2020).

Rotifers are fundamental in the ecological structure of aquatic ecosystems. These organisms respond quickly to environmental stresses caused by heavy metals, pesticides, pharmaceuticals, among others; hence their relevance in ecotoxicological studies (Snell and Marcial, 2017). The most used endpoints to estimate ecological risk for rotifer populations are acute $\left(\mathrm{LC}_{50}\right)$ and chronic (instantaneous growth rate 
(r)) toxicity tests (Rico-Martínez et al., 2013; González-Pérez et al., 2018). The $r$ is a good measure of response to toxicants since it integrates potentially complex interactions among life-history traits, including reproductive and mortality rates (Forbes and Calow, 1999), which is unattainable through acute tests.

Many aquatic organisms live in environments polluted by a cocktail of toxic substances, including heavy metals and pharmaceuticals. Despite this general assumption, the mixture toxicity of heavy metals and drugs is examined separately in most cases (Watanabe et al., 2015; Lynch et al., 2015). Few studies have examined the toxicity of mixtures like the ones mentioned above (Almeida et al., 2018; Jia et al., 2020). Taking on account (1) the current relevance of $\mathrm{CQ}$ as an emerging pollutant, (2) widespread $\mathrm{Cu}$ contamination in marine and coastal environment and (3) that in a real scenario, environmental pollutants typically occur as mixtures rather than as individual pollutants (Cedergreen 2014), this work aimed to assess the toxicity of CQ alone and in combination with $\mathrm{Cu}$ to the euryhaline rotifer Proales similis. The potential of this species as a reliable model organism for marine ecotoxicological studies has been previously demonstrated by Rebolledo et al. (2018), Snell et al. (2019) and Kim et al. (2021).

\section{Materials And Methods}

\section{Test species}

Proales similis de Beauchamp 1907 (Rotifera: Monogononta) was isolated from a shrimp farm of Litopenaeus vannamei located in north-western Mexico (Rebolledo et al., 2018). Since then, we keep this rotifer species under laboratory conditions. A monoclonal culture of the test rotifer was established using $15 \%$ of artificial seawater (Instant Ocean, Aquarium Systems, Inc.) at $25 \pm 1{ }^{\circ} \mathrm{C}$. Rotifers were fed with single-cell marine algae Nannochloropsis oculata at $3 \times 10^{6}$ cells $\mathrm{mL}^{-1}$. Several egg-bearing individuals were separated in a $20 \mathrm{~mL}$ medium to obtain neonates ( $<8 \mathrm{~h}$-old) for each experiment. Proales similis is a euryhaline rotifer suitable for ecotoxicological tests in different salinity scenarios ranging from 5 to $35 \%$ (Rebolledo et al., 2021). For all bioassays, a salinity of $15 \%$ o was used as representative of inland sections of estuarine and lagoon ecosystems, where significant levels of pharmaceuticals and heavy metals could be regularly discharged in municipal effluents.

\section{Chemicals}

Copper and CQ stock solutions were prepared by dissolving an appropriate quantity of $\mathrm{CuSO}_{4 \cdot{ }_{5}} \mathrm{H}_{2} \mathrm{O}$ (J.T. Baker, >99\%) and $\mathrm{N}^{4}$-(7-Chloro-4-quinolinyl)- $\mathrm{N}^{1}, \mathrm{~N}^{1}$-dimethyl-1,4-pentanediamine diphosphate salt (CAS 5063-5 from Sigma-Aldrich, >98.5\%), respectively, in milli-Q water to obtain a stock solution of $1 \mathrm{mg} \mathrm{mL}^{-1}$.

Acute toxicity test (CQ)

Initially, we performed range-finding tests of CQ concentrations for acute toxicity testing in $P$. similis. Subsequently, six nominal concentrations of CQ $(0.5,2.5,5.0,7.5,12.5$ and $20.0 \mathrm{mg} / \mathrm{L})$ plus one negative control (0) were used to evaluate the 24-h $\mathrm{LC}_{50}$. Toxicity tests were conducted in borosilicate glass vials 
containing $3 \mathrm{~mL}$ of medium ( 28 vials $=6$ concentrations +1 control $\times 4$ replicates). Ten neonates were

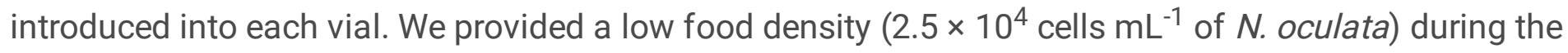
tests in order to avoid mortality above $10 \%$, as noted when unfed. All tests were incubated in the dark at $25 \pm 1{ }^{\circ} \mathrm{C}$ for $24 \mathrm{~h}$. After exposure, the $\mathrm{LC}_{50}$ values of $\mathrm{CQ}$ and their $95 \%$ confidence limits were calculated using the Probit method (Finney 1971).

\section{Reproductive assay}

According to Hernández-Flores and Rico-Martínez (2006), we measured the single and combined toxicity of $\mathrm{CQ}$ and $\mathrm{Cu}$ on the rotifer $P$. similis through chronic toxicity reproductive 5-day tests (static non-renewal testing solution). Single chronic toxicity tests were performed using an application factor (AF) of 0.05 , $0.1,0.3$ and 0.5 by multiplying the $24-\mathrm{h} \mathrm{LC}_{50}$ values of CQ $(4250 \mu \mathrm{g} / \mathrm{L})$ and $\mathrm{Cu}(68 \mu \mathrm{g} / \mathrm{L}$ (Rebolledo et al., 2021)). The combined toxicity of $\mathrm{Cu}$ and $\mathrm{CQ}$ was evaluated through five mixtures using $0.05,0.1,0.3$ and 0.5 as AF (see Table 1). Briefly, nine neonates were introduced into a $3 \mathrm{~mL}$ medium with respective single and combined concentrations of $\mathrm{CQ}$ and $\mathrm{Cu}$. Rotifers were fed $\mathrm{N}$. oculata at a density of $1.25 \times 10^{6}$ cells $\mathrm{mL}^{-1}$ for five days. Each treatment had one negative control group and five replicates. All bioassays were incubated in the dark at $25^{\circ} \mathrm{C}$ for five days. After exposure, the final population densities of the rotifers were counted under a stereomicroscope. Population growth rate $\left(r, \mathrm{~d}^{-1}\right)$ was calculated using the formula $r=\left(\ln N_{t}-\ln N_{0}\right) / T$, where $N_{t}$ is density at time $T, N_{0}$ is density at time 0 , and $T$ is 5 days.

The concentration addition model (Broderius et al., 2005) was utilized to assess potential mixture effects of $\mathrm{CQ}$ and $\mathrm{Cu}$. Additive effects were obtained from the sum of dividing the growth rate $\left(r, \mathrm{~d}^{-1}\right)$ value from the CQ-Cu mixture by the corresponding $r, \mathrm{~d}^{-1}$ value from the sum of the toxicity of the individual chemicals. If the result was $<0.8$, the action represents potential synergism (more than additive); if it was $0.8<>1.2$, an additive action is indicated (concentration addition); and if it was $>1.2$, the action indicates potential antagonism (less than additive).

Statistical analysis

One-way analysis of variance (ANOVA) followed by a Tukey's post-hoc test was used to compare the statistical differences between group means, where $P<0.05$ was considered significant. All data are expressed as mean \pm standard errors (SE) based on five replicate recordings.

\section{Results}

The 24-h $\mathrm{LC}_{50}$ value of CQ for $P$. similis was $4.25 \mathrm{mg} / \mathrm{L}$, with a $95 \%$ confidence interval of 3.0 to $5.9 \mathrm{mg} / \mathrm{L}$. In general, growth rates $\left(r, \mathrm{~d}^{-1}\right)$ of $P$. similis varied from $0.50 \pm 0.02$ to $0.52 \pm 0.01$ in the control groups. At chronic CQ exposure, ranged from $0.19 \pm 0.01$ to $0.39 \pm 0.01 \mathrm{~d}^{-1}$ (Fig. 1, M1). An increase in CQ concentration from $212(0.05 \mathrm{AF})$ to $2125 \mu \mathrm{g} / \mathrm{L}$ (0.5 AF) reduced the growth rates up to $60 \%$ with respect to the controls. Regarding chronic Cu toxicity, growth rates decreased from $0.42 \pm 0.01$ to $0.09 \pm 0.02 \mathrm{~d}^{-1}$,

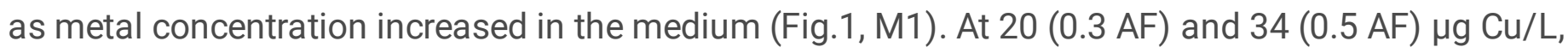


toxicity reduced growth by $58(0.21 \pm 0.01)$ and $82 \%(0.09 \pm 0.02)$, respectively, as compared to the controls $(0.52 \pm 0.01)$.

Single and mixture toxicity of $\mathrm{CQ}$ and $\mathrm{Cu}$ to $P$. similis is shown in Figure 1. Under the M1 mixture, growth rates decreased from $0.29 \pm 0.01$ to $-0.14 \pm 0.03 \mathrm{~d}^{-1}$ as AF increased in the medium. The CQ and $\mathrm{Cu}$ mixture effects versus single $C Q$ and $\mathrm{Cu}$ exposure showed a synergistic response (Table 2). For example, at a single exposure of $C Q$ at low $A F(0.05)$, the $r$ value was $0.39 \pm 0.01 \mathrm{~d}^{-1}$. Conversely, under the CQ-Cu mixture at $0.05 \mathrm{AF}$ was $0.29 \pm 0.01 \mathrm{~d}^{-1}$, that is a $25 \%$ reduction. A similar response was observed when comparing the single toxicity of $\mathrm{Cu}$ versus the $\mathrm{CQ}-\mathrm{Cu}$ mixture at $0.05 \mathrm{AF}$ (30\% reduction). At single exposure of $\mathrm{CQ}$ and $\mathrm{Cu}$ at $0.3 \mathrm{AF}$, growth rates were $0.19 \pm 0.01$ and $0.21 \pm 0.01 \mathrm{~d}^{-1}$, respectively. In contrast, under the CQ-Cu mixture at $0.3 \mathrm{AF}$, it was $0.09 \pm 0.02 \mathrm{~d}^{-1}$, reducing over $50 \%$. The most evident synergistic effect was observed when the rotifers were exposed to a CQ-Cu mixture at 0.5 AF (Fig. 1, M1; Table 2). One-way ANOVA shows significant differences $(P<0.05)$ when comparing the individual toxicity of each chemical against the mixture at the same AF.

Regarding the M2 mixture, low AF (0.05) of CQ $(213 \mu \mathrm{g} / \mathrm{L})$ combined with Cu decreased growth rates from $0.29 \pm 0.1$ to $-0.03 \pm 0.01 \mathrm{~d}^{-1}$ as the AF for Cu increases in the medium (Fig. 1, M2). Under these mixtures, growth rates decreased significantly $(P<0.05)$ with respect to the individual toxicity of $C Q$ at $0.05 \mathrm{AF}$ and $\mathrm{Cu}$ at 0.1 and $0.5 \mathrm{AF}$. We did not observe significant differences $(P>0.05)$ among single exposure to $\mathrm{Cu}$ at $0.3 \mathrm{AF}$ and the mixture based on 0.05 AF of $\mathrm{CQ}+0.3 \mathrm{AF}$ of $\mathrm{Cu}$ (Fig.1, M2). Synergistic effects were detected when combined $213 \mu \mathrm{g} \mathrm{CQ} / \mathrm{L}(0.05 \mathrm{AF})$ with $0.1,0.3$ and $0.5 \mathrm{AF}$ of $\mathrm{Cu}$ (Table 2). For $\mathrm{Cu}$, two synergistic and one additive effect were detected (Table 2).

The M3 mixture (Fig. 1) evidenced that all combinations of CQ at $0.1 \mathrm{AF}(425 \mu \mathrm{g} \mathrm{L})+\mathrm{Cu}$ at $0.05,0.3$ and $0.5 \mathrm{AF}$ produced a significant $(\mathrm{P}<0.05)$ decrease in the growth rates when compared to single $\mathrm{CQ}$ and $\mathrm{Cu}$ exposure. A mixture of $\mathrm{CQ}$ at $0.1 \mathrm{AF}+\mathrm{Cu}$ at $0.3 \mathrm{AF}$ resulted in synergistic effects; 62 and $42 \%$ reduction in growth rates observed in the individual toxicity of $\mathrm{CQ}$ at $0.1 \mathrm{AF}$ and $\mathrm{Cu}$ at $0.3 \mathrm{AF}$, respectively. Using a mixture of $\mathrm{CQ}$ at $0.1 \mathrm{AF}+\mathrm{Cu}$ at $0.5 \mathrm{AF}$, a negative $r$-value was observed $\left(-0.05 \mathrm{~d}^{-1}\right)$; this was not observed in a single $\mathrm{CQ}$ and $\mathrm{Cu}$ toxicity at the same AF (Fig. 1; M3). A mixture based on CQ at $0.1 \mathrm{AF}+\mathrm{Cu}$ at 0.05 AF results in an additive effect for $C Q$ and $\mathrm{Cu}$ at the same AF (Table 2). Synergistic effects were detected as Cu concentrations increased in the M3.

The M4 mixture indicated that growth rates were $22 \%$ higher when $P$. similis was exposed to CQ at $0.3 \mathrm{AF}$ $(1275 \mu \mathrm{g} / \mathrm{L})+\mathrm{Cu}$ at $0.05 \mathrm{AF}$, compared to single CQ exposure at $0.3 \mathrm{AF}$ (Fig. 1; M4), but a one-way ANOVA showed no significant differences $(P>0.05)$ among the individual $C Q$ exposure at $0.3 \mathrm{AF}$ and the mixtures of $0.3+0.05 \mathrm{AF}$ and $0.3+0.1 \mathrm{AF}(\mathrm{CQ}-\mathrm{Cu})$. Under a mixture of $\mathrm{CQ}$ at $0.3 \mathrm{AF}+\mathrm{Cu}$ at $0.5 \mathrm{AF}, \mathrm{a}$ negative $r$ value was produced $\left(-0.04 \mathrm{~d}^{-1}\right)$; whilst a single exposure, the $r$ value was $0.19 \mathrm{~d}^{-1}$ at $0.3 \mathrm{AF}$ of $\mathrm{CQ}$ and $0.10 \mathrm{~d}^{-1}$ at $0.5 \mathrm{AF}$ of $\mathrm{Cu}$. Combinations of CQ at $0.3 \mathrm{AF}+\mathrm{Cu}$ at $0.05 \mathrm{AF}$ and CQ at $0.3+\mathrm{Cu}$ at 0.1 AF caused a significant $(P<0.05)$ decrease of 40 to $50 \%$ in growth rates compared to single Cu exposure at the same AF. An antagonism effect was detected at $0.3 \mathrm{AF}$ of $\mathrm{CQ}+0.05 \mathrm{AF}$ of $\mathrm{Cu}$. In the case of $\mathrm{Cu}$, 
this mixture resulted in an additive effect (Table 2). Synergistic effects were observed as the concentrations of $\mathrm{CQ}$ and $\mathrm{Cu}$ increased in the medium.

Regarding the chronic effect of the M5 mixture, combinations of CQ at 0.5 AF $(2125 \mu \mathrm{g} / \mathrm{L})+\mathrm{Cu}$ at 0.1 and $0.3 \mathrm{AF}$ decreased significantly $(\mathrm{P}<0.05)$ growth rates when compared to single chemical exposure (Fig. 1; M5). A mixture of $\mathrm{CQ}$ at $0.5 \mathrm{AF}+\mathrm{Cu}$ at $0.05(3.5 \mu \mathrm{g} / \mathrm{L})$ did not differ from the individual CQ toxicity at $0.5 \mathrm{AF}$. However, it caused a $50 \%$ reduction in growth rates than single $\mathrm{Cu}$ exposure at the same AF. A mixture of $\mathrm{CQ}$ at $0.5 \mathrm{AF}+\mathrm{Cu}$ at $0.3 \mathrm{AF}(20 \mu \mathrm{g} / \mathrm{L})$ resulted in a low $r$ value $\left(0.05 \mathrm{~d}^{-1}\right)$. A more noticeable synergistic response was observed under a mixture of $\mathrm{CQ}$ at $0.5 \mathrm{AF}+\mathrm{Cu}$ at $0.3 \mathrm{AF}$; growth rates decreased more than $75 \%$ than single $\mathrm{Cu}$ and $\mathrm{CQ}$ exposure at the same AF. Two additive effects were found for $\mathrm{CQ}$ and one synergistic response at $0.5 \mathrm{AF}$ of $\mathrm{CQ}+0.3 \mathrm{AF}$ of $\mathrm{Cu}$. For $\mathrm{Cu}$, all combinations induced synergistic effects (Table 2).

\section{Discussion}

In the present study, we examined the toxicity of chloroquine due to its current and future potential applications to treat several human diseases. Its important use and high potential to being persistent make it of particular concern for ecotoxicological studies. Presumably, as has occurred with other pharmaceuticals drugs, CQ will gain more ecotoxicological relevance after this worldwide crisis (Essid et al., 2020; Ali et al., 2021; Kuroda et al., 2021).

Hitherto, limited information is available regarding the acute and chronic toxicity of CQ in aquatic biota. As a first approximation of CQ toxicity, the euryhaline rotifer $P$. similis has a $24-\mathrm{h} \mathrm{LC}_{50}$ of $4.25 \mathrm{mg} / \mathrm{L}$. This result is very close to that for the freshwater rotifer Brachionus calyciflorus $(4.39 \mathrm{mg} / \mathrm{L})$ and the anostracan Thamnocephalus platyurus $(4.70 \mathrm{mg} / \mathrm{L})$, organisms widely used in ecotoxicological studies (Calleja et al., 1994; Nalecz-Jawecki and Persoone, 2006). Proales similis seems to be more sensitive to CQ than the cladoceran Daphnia magna (24-h EC50, 21.5 to $43 \mathrm{mg} / \mathrm{L}$ ) and the crustacean Streptocephalus proboscideus (24-h EC50, $11.6 \mathrm{mg} / \mathrm{L}$ ) (Calleja et al., 1994; Zurita et al., 2005). It is documented that some vertebrates, such as Cyprinus carpio, have a $96-\mathrm{h} \mathrm{LC}_{50}$ of $31.6 \mathrm{CQ} \mathrm{mg/mL}$ (Ramesh et al., 2018) that far exceeds the tolerance of the previously mentioned invertebrates. Considering that the sensitivity of $P$. similis to $\mathrm{CQ}$ is within the range reported in standard test species for ecotoxicological assays, we suggest that this marine rotifer be used as an indicator for ecological risk assessment of emerging pollutants that currently deserve more attention.

The chronic toxicity of CQ has been rarely examined in aquatic organisms (Ramesh et al., 2018). As many as $10 \mu \mathrm{g} C Q / L$ have been reported in the field, mainly near hospital areas (Olatunde et al., 2014). It is predicted that this concentration in aquatic ecosystems will increase due to the COVID-19 pandemic (Espejo et al., 2020; Kuroda et al., 2021). In our present study, the chronic test concentrations were based on the $\mathrm{LC}_{50}$ value of $\mathrm{CQ}$ for $P$. similis. These concentrations have not yet been detected in the field. However, they can be predictive not only for this rotifer species but also for other zooplankton species with a similar response to CQ. Obtained data indicate that from 213 to $2125 \mu \mathrm{g} C Q / L$ (5 to $50 \%$ of $\mathrm{LC}_{50}$ ), 
the growth rates of $P$. similis are significantly reduced (22 to $60 \%)$. A similar amount $(200 \mu \mathrm{g} / \mathrm{L}$ ) of other pharmaceuticals, such as amoxicillin, cause significant effects on the rate of population increase ( $60 \%$ of reduction) on Brachionus havanaensis (González-Pérez et al., 2016). Unlike P. similis, the growth of some aquatic organisms is inhibited at pharmaceutical concentrations ranging from 5.0 to $300 \mathrm{mg} / \mathrm{L}$ (Watanabe et al., 2015; Godoy et al., 2019), or even as much as 2000 mg/L (Magdaleno et al., 2015). Recently, Ali et al. (2021) found that chronic exposure to high hydroxychloroquine (a less toxic derivative of CQ) concentrations (31.62 and $63.24 \mu \mathrm{g} / \mathrm{mL}$ ) impact the abundance and diversity of marine nematodes negatively. Therefore, the present data highlights the toxic potential of $C Q$ at moderate concentrations for marine zooplankton populations.

Copper toxicity is known in a wide diversity of aquatic organisms, including zooplankton (Arnold et al., 2011). Our results agree with those of Rebolledo et al. (2021); $P$. similis is more sensitive to Cu than other saline or marine rotifers. For example, at $34 \mu \mathrm{g} \mathrm{Cu} / \mathrm{L}\left(50 \%\right.$ of the $\left.\mathrm{LC}_{50}\right)$, growth rates of $P$. similis are reduced by as much as $83 \%$. At the same time, populations of $B$. rotundiformis can remain unaffected at a chronic exposure of 31 to $125 \mu \mathrm{g} \mathrm{CuSO}_{4} / \mathrm{L}$ (Gama-Flores et al., 2005). Conversely, it is suggested that $B$. plicatilis is even more resistant since it can grow under a chronic concentration of $500 \mu \mathrm{g} \mathrm{CuSO}_{4} / \mathrm{L}$ that exceeds the $\mathrm{LC}_{50}$ of $P$. similis (Luna-Andrade et al., 2002; Rebolledo et al., 2021). Snell et al. (2019) found that some complex strains of $B$. plicatilis might be more sensitive to Cu compared to $P$. similis, therefore suggests that their sensitivity is not a generality compared to other marine rotifers. Cu concentrations used in our chronic tests ( 3.5 to $34 \mu \mathrm{g} / \mathrm{L}$ ) are below some levels detected (ca. $50 \mu \mathrm{g} / \mathrm{L}$ ) in estuaries and coastal marine environments (e.g., Vazquez et al., 1999; Jonathan et al., 2011). It is assumed that the demographic parameters of $P$. similis, as well as other zooplankton taxa with high sensitivity to $\mathrm{Cu}$, are negatively affected by chronic metal exposure that exceeds the tolerance threshold of this species (Bechmann 1994; Schuler et al., 2008; Kwok et al., 2008; Arnold et al., 2011).

Usually, the toxicities of pollutants mixtures are reported more as additive than synergistic effects (Cedergreen 2014), which has led regulatory authorities to consider that the toxicity of a combination of chemicals will be approximately additive (Walker et al., 2012). To our knowledge, this is the first study to demonstrate the mixture toxicity of $\mathrm{CQ}$ and $\mathrm{Cu}$ in marine invertebrates. The present findings underline the risk of the different mixtures of these two chemicals; in most cases, they induced a synergistic effect on the population growth rate of $P$. similis. Contrary to Almeida et al. (2018), who found that a mixture of drugs (carbamazepine and cetirizine) with a heavy metal (Cd) had lower biological effects than the contaminants alone in the clam Ruditapes philippinarum and that the metal attenuated the drugs effects; in this study, the combined toxicity of $\mathrm{CQ}$ with a heavy metal $(\mathrm{Cu})$ exacerbated the vulnerability of the organisms to the drug, as reported by Ji et al. (2020). It is not the first case that the combination of $\mathrm{Cu}$ with other pollutants induces synergistic effects on the growth and survival of marine invertebrates (Bao et al., 2013; 2014). A synergistic effect of the CQ-Cu mixture will have occurred when these chemicals have been combined at high concentrations. Tested concentrations of $\mathrm{Cu}$ are within those detected in marine environments (Jonathan et al., 2011), but in the case of CQ, these are well below environmental concentrations (Olatunde et al., 2014). Thus, their importance as synergists within naturally occurring 
realistic scenarios is a relatively minor concern (Cedergreen 2014). Nevertheless, this aspect should not be understated, given the current environmental threats.

Copper has been recognized as one most toxic heavy metals to aquatic invertebrates. In particular, $\mathrm{Cu}$ is more toxic than $\mathrm{Fe}, \mathrm{Pb}, \mathrm{Cd}, \mathrm{Zn}, \mathrm{As}$ and $\mathrm{Cr}$ to $P$. similis (Rebolledo et al., 2021). In this work, it was noticed that growth rates were more affected by $\mathrm{Cu}$ at high concentrations than by $\mathrm{CQ}$. When these chemicals were combined, we assumed that $\mathrm{Cu}$ exerted more pressure than $\mathrm{CQ}$, thus intensified the sensitivity of organisms to the tested drug. Therefore, the widespread contamination of $\mathrm{Cu}$ in coastal environments and its high toxicity to aquatic life should be considered more frequently for the environmental risk assessment of chemical mixtures. It is essential to mention that the toxicity of mixtures of CQ and Cu to $P$. similis could increase under ecological stress (Shahid et al., 2019; Rebolledo et al., 2021). Future research should examine this aspect.

\section{Conclusion}

According to the literature, the sensitivity of $P$. similis to $C Q$ found in the present study is within the range reported in standard test species for ecotoxicological testing. We suggest that this rotifer species serve as a test organism to investigate the risk assessment of emerging pollutants in marine environments. In general, a low concentration exposure of each chemical tested (CQ and $\mathrm{Cu}$ ) was enough to exert significant effects on the population growth of rotifers; these were intensified when the compounds acted in combination. CQ-Cu mixtures exhibited a strong synergistic effect on Proales mainly as the concentrations of each chemical increased in the medium. Synergistic response stresses the potential hazard that these combined chemicals may have on the aquatic systems and evidence of the possible environmental risks associated with emerging pollutants that have originated during the COVID-19 pandemic. At present, we must show the effects of global pollution from a more realistic perspective, where pollution by a single chemical is rare or does not exist.

\section{Declarations}

Acknowledgements Uriel Arreguin Rebolledo thanks CONACyT (490764) for the financial support.Thanks to H. Bojórquez-Leyva for the support of the laboratory.

Funding This work was supported by the institutional (ICML, UNAM) project titled "Biogeoquímica de los nutrientes y oligoelementos en sistemas acuáticos: acumulación, distribución, transferencia, efectos y ciclaje" (year 2020).

Author contributions All authors have participated in (a) conception and design, or analysis and interpretation of the data; (b) drafting the article or revising it critically for important intellectual content; and (c) approval of the final version.

\section{Compliance with ethical standards}


Conflict of interest The authors declare no competing interests.

Consent to participate All authors consent to participate.

Consent for publication All authors consent for publication.

\section{References}

1. Almeida Â, Calisto V, Esteves VI, Schneider RJ, Soares AMVM, Figueira E, Freitas R (2018) Effects of single and combined exposure of pharmaceutical drugs (carbamazepine and cetirizine) and a metal (cadmium) on the biochemical responses of R. philippinarum. Aquat Toxicol 198:10-19. https://doi.org/10.1016/j.aquatox.2018.02.011

2. Ali MB, Hedfi A, Almalki M, Karachle PK, Boufahja F (2021) Toxicity of hydroxychloroquine, a potential treatment for COVID-19, on free-living marine nematodes. Mar Pollut Bull 167:112361. https://doi.org/10.1016/j.marpolbul.2021.112361

3. Ansari TM, Marr IL, Tariq N (2003) Heavy metals in marine pollution perspective-a mini review. J Appl Sci 4:1-20. https://doi.org/10.3923/jas.2004.1.20

4. Arnold WR, Diamond RL, Smith DS (2011) Acute and chronic toxicity of copper to the euryhaline rotifer, Brachionus plicatilis ("L" Strain). Arch. Environ Contam Toxicol 60:250-260. https://doi.org/10.1007/s00244-010-9556-8

5. Attia YA, El-Saadony MT, Swelum AA, Qattan SY, Al-Qurashi AD, Asiry KA., ... \& Abd El-Hack ME (2021) COVID-19: pathogenesis, advances in treatment and vaccine development and environmental impact -an updated review. Environ Sci Pollut Res 1-24. https://doi.org/10.1007/s11356-021-13018-1

6. Bao VW, Leung KM, Lui GC, Lam MH (2013) Acute and chronic toxicities of Irgarol alone and in combination with copper to the marine copepod Tigriopus japonicus. Chemosphere 90:1140-1148. https://doi.org/10.1016/j.chemosphere.2012.09.022

7. Bao VW, Lui GC, Leung KM (2014) Acute and chronic toxicities of zinc pyrithione alone and in combination with copper to the marine copepod Tigriopus japonicus. Aquat Toxicol 157:81-93. https://doi.org/10.1016/j.aquatox.2014.09.013

8. Bechmann RK (1994) Use of life tables and LC $_{50}$ tests to evaluate chronic and acute toxicity effects of copper on the marine copepod tisbe furcata (baird). Environ Toxicol Chem 13:1509-1517. https://doi.org/10.1002/etc.5620130913

9. Broderius SJ, KahI MD, Elonen GE, Hammermeister DE, Hoglund MD (2005) A comparison of the lethal and sublethal toxicity of organic chemical mixtures to the fathead minnow (Pimephales promelas). Environ Toxicol Chem 24: 3117-3127. https://doi.org/10.1897/05-094R.1

10. Brodin T, Piovano S, Fick J, Klaminder J, Heynen M, Jonsson M (2014) Ecological effects of pharmaceuticals in aquatic systems-impacts through behavioural alterations. Philos Trans R Soc B Biol Sci 369:20130580. https://doi.org/10.1098/rstb.2013.0580 
11. Bunke D, Moritz S, Brack W, Herráez DL, Posthuma L, Nuss M (2019) Developments in society and implications for emerging pollutants in the aquatic environment. Environ Sci Eur 31:32. https://doi.org/10.1186/s12302-019-0213-1

12. Calleja MC, Persoone G, Geladi P (1994) Comparative acute toxicity of the first 50 Multicentre Evaluation of In Vitro Cytotoxicity chemicals to aquatic non-vertebrates. Arch Environ Contam Toxicol 26:69-78. https://doi.org/10.1007/BF00212796

13. Cedergreen N (2014) Quantifying Synergy: A systematic review of mixture toxicity studies within environmental toxicology. PLoS One 9:e96580. https://doi.org/10.1371/journal.pone.0096580

14. Colson P, Rolain JM, Raoult D (2020) Chloroquine for the 2019 novel coronavirus SARS-CoV-2. Int J Antimicrob Agents 55:105923. https://doi.org/10.1016/j.ijantimicag.2020.105923

15. Delogu I, de Lamballerie X (2011) Chikungunya disease and chloroquine treatment. J Med Virol 83(6): https://doi.org/10.1002/jmv.22019

16. Espejo W, Celis JE, Chiang G, Bahamonde P (2020) Environment and COVID-19: Pollutants, impacts, dissemination, management and recommendations for facing future epidemic threats. Sci Total Environ 747:141314. https://doi.org/10.1016/j.scitotenv.2020.141314

17. Essid N, Allouche M, Lazzem M, Harrath AH, Mansour L, Alwasel S, Mahmoudi E, Beyrem H, Boufahja $F(2020)$ Ecotoxic response of nematodes to ivermectin, a potential anti-COVID-19 drug treatment. Mar Pollut Bull 157:111375. https://doi.org/10.1016/j.marpolbul.2020.111375

18. Fang TH, Nan FH, Chin TS, Feng HM (2012) The occurrence and distribution of pharmaceutical compounds in the effluents of a major sewage treatment plant in Northern Taiwan and the receiving coastal waters. Mar Pollut Bull 64:1435-1444. https://doi.org/10.1016/j.marpolbul.2012.04.008

19. Finney DJ (1971) Probit Analysis (3th edn.), Cambridge University Press, Cambridge (1971), p. 333

20. Forbes VE, Calow P (1999) Is the per capita rate of increase a good measure of population-level effects in ecotoxicology? Environ Toxicol Chem 18:1544-1556. https://doi.org/10.1002/etc.5620180729

21. Gama-Flores JL, Sarma SSS, Nandini S (2005) Interaction among copper toxicity, temperature and salinity on the population dynamics of Brachionus Rotundiformis (Rotifera). Hydrobiologia 546:559-568. https://doi.org/10.1007/s10750-005-4300-5

22. Gavrilescu M, Demnerová K, Aamand J, Agathos S, Fava F (2015) Emerging pollutants in the environment: Present and future challenges in biomonitoring, ecological risks and bioremediation. $\mathrm{N}$ Biotechnol 32:147-156. https://doi.org/10.1016/j.nbt.2014.01.001

23. Godoy AA, de Oliveira ÁC, Silva JGM, Azevedo CC de J, Domingues I, Nogueira AJA, Kummrow F (2019) Single and mixture toxicity of four pharmaceuticals of environmental concern to aquatic organisms, including a behavioral assessment. Chemosphere 235:373-382. https://doi.org/10.1016/j.chemosphere.2019.06.200

24. Gu JD, Wang YS (2015) Coastal and marine pollution and ecotoxicology. Ecotoxicology 24:14071410. https://doi.org/10.1007/s10646-015-1528-3 
25. González-Pérez BK, Sarma SSS, Castellanos-Páez ME, Nandini S (2018) Multigenerational effects of triclosan on the demography of Plationus patulus and Brachionus havanaensis (Rotifera). Ecotoxicol Environ Saf 147:275-282. https://doi.org/10.1016/j.ecoenv.2017.08.049

26. González-Pérez BK, Sarma SSS, Nandini S (2016) Effects of selected pharmaceuticals (ibuprofen and amoxicillin) on the demography of Brachionus calyciflorus and Brachionus havanaensis (Rotifera). Egypt J Aquat Res 42:341-347. https://doi.org/10.1016/j.ejar.2016.09.003

27. Hernández-Flores S, Rico-Martínez, R (2006) Study of the effects of $\mathrm{Pb}$ and Hg toxicity using a chronic toxicity reproductive 5-day test with the freshwater rotifer Lecane quadridentata. Environ Toxicol 21:533-540. https://doi.org/10.1002/tox.20218

28. Jia D, Li X, Du S, Xu N, Zhang W, Yang R, Yunhai Z, He Y, Zhang Y (2020) Single and combined effects of carbamazepine and copper on nervous and antioxidant systems of zebrafish (Danio rerio). Environ Toxicol 35:1091-1099. https://doi.org/10.1002/tox.22945

29. Jonathan MP, Roy PD, Thangadurai N, Srinivasalu S, Rodríguez-Espinosa PF, Sarkar SK, Lakshumanan C, Navarrete-López M, Muñoz-Sevilla NP (2011) Metal concentrations in water and sediments from tourist beaches of Acapulco, Mexico. Mar Pollut Bull 62:845-850. https://doi.org/10.1016/j.marpolbul.2011.02.042

30. Kim DH, Kim MS, Hagiwara A, Lee JS (2021) The genome of the minute marine rotifer Proales similis: Genome-wide identification of $401 \mathrm{G}$ protein-coupled receptor (GPCR) genes. Comp Biochem Physiol Part D Genomics Proteomics 100861. https://doi.org/10.1016/j.cbd.2021.100861

31. Kuroda K, Li C, Dhangar K, Kumar M (2021) Predicted occurrence, ecotoxicological risk and environmentally acquired resistance of antiviral drugs associated with COVID-19 in environmental waters. Sci Total Environ 776:145740. https://doi.org/10.1016/j.scitotenv.2021.145740

32. Kwok KWH, Leung KMY, Bao VWW, Lee JS (2008) Copper toxicity in the marine copepod Tigropus japonicus: Low variability and high reproducibility of repeated acute and life-cycle tests. Mar Pollut Bull 57:632-636. https://doi.org/10.1016/j.marpolbul.2008.03.026

33. Liu K, Zhang D, Xiao X, Cui L, Zhang H (2020) Occurrence of quinotone antibiotics and their impacts on aquatic environment in typical river-estuary system of Jiaozhou Bay, China. Ecotoxicol Environ Saf 190:109993. https://doi.org/10.1016/j.ecoenv.2019.109993

34. Luna-Andrade A, Aguilar-Duran, R, Nandini S, Sarma SSS (2002) Combined effects of copper and microalgal (Tetraselmis suecica) concentrations on the population growth of Brachionus plicatilis Müller (Rotifera). Water, Air, Soil Pollut 141:143-153. https://doi.org/10.1023/A:1021346512560

35. Lynch NR, Hoang TC, O'Brien TE (2016) Acute toxicity of binary-metal mixtures of copper, zinc, and nickel to Pimephales promelas: Evidence of more-than-additive effect. Environ Toxicol Chem 35:446-457. https://doi.org/10.1002/etc.3204

36. Magdaleno A, Saenz ME, Juárez AB, Moretton J (2015) Effects of six antibiotics and their binary mixtures on growth of Pseudokirchneriellasubcapitata. Ecotoxicol Environ Saf 113:72-78. https://doi.org/10.1016/j.ecoenv.2014.11.021 
37. Midassi S. Bedoui A, Bensalah N (2020) Efficient degradation of chloroquine drug by electro-Fenton oxidation: Effects of operating conditions and degradation mechanism. Chemosphere 260:127558. https://doi.org/10.1016/j.chemosphere.2020.127558

38. Nalecz-Jawecki G, Persoone G (2006) Toxicity of selected pharmaceuticals to the Anostracan crustacean Thamnocephalus platyurus - Comparison of sublethal and lethal effect levels with the $1 \mathrm{~h}$ Rapidtoxkit and the $24 \mathrm{~h}$ thamnotoxkit microbiotests. Environ Sci Pollut Res - Int 13:22-27. https://doi.org/10.1065/espr2006.01.005

39. Olatunde JO, Chimezie A, Tolulope B, Aminat TT (2014) Determination of pharmaceutical compounds in surface and underground water by solid phase extraction-liquid chromatography. $\mathrm{J}$ Environ Chem Ecotoxicol 6:20-26. https://doi.org/10.5897/jece2013.0312

40. Páez-Osuna F, Osuna-Martínez CC (2015) Bioavailability of cadmium, copper, mercury, lead, and zinc in subtropical coastal lagoons from the Southeast Gulf of California using mangrove oysters (Crassostrea corteziensis and Crassostrea palmula). Arch Environ Contam Toxicol 68:305-316. https://doi.org/10.1007/s00244-014-0118-3

41. Pastick KA, Okafor EC, Wang F, Lofgren SM, Skipper CP, Nicol MR, Pullen MF, Rajasingham R, McDonald EG, Lee TC, et al. (2020) Review: hydroxychloroquine and chloroquine for treatment of SARS-CoV-2 (COVID-19) Open Forum Infect. In Dis (Vol. 7, No. 4, pp. 1-9).

42. Plantone $D$, Koudriavtseva $T$ (2018) Current and future use of chloroquine and hydroxychloroquine in infectious, immune, neoplastic, and neurological diseases: a mini-review. Clin Drug Investig 38:653671. https://doi.org/10.1007/s40261-018-0656-y

43. Ramesh M, Anitha S, Poopal RK, Shobana C (2018) Evaluation of acute and sublethal effects of chloroquine $\left(\mathrm{C}_{18} \mathrm{H}_{26} \mathrm{CIN}_{3}\right)$ on certain enzymological and histopathological biomarker responses of a freshwater fish Cyprinus carpio. Toxicol Reports 5:18-27. https://doi.org/10.1016/j.toxrep.2017.11.006

44. Rebolledo UA, Nandini S, Sánchez-Escobar O, Sarma SSS (2018) Combined effects of temperature and salinity on the demographic response of Proales similis (Beauchamp, 1907) and Brachionus plicatilis (Müller, 1786) (Rotifera) to mercury. Chemosphere 202:312-321. https://doi.org/10.1016/j.chemosphere.2018.03.111

45. Rebolledo UA, Páez-Osuna F, Fernández R (2021) Single and mixture toxicity of $\mathrm{As}, \mathrm{Cd}, \mathrm{Cr}, \mathrm{Cu}, \mathrm{Fe}, \mathrm{Hg}$, $\mathrm{Ni}, \mathrm{Pb}$, and $\mathrm{Zn}$ to the rotifer Proales similis under different salinities. Environ Pollut 116357. https://doi.org/10.1016/j.envpol.2020.116357

46. Rico-Martínez R, Snell TW, Shearer, TL. (2013) Synergistic toxicity of Macondo crude oil and dispersant Corexit 9500A® to the Brachionus plicatilis species complex (Rotifera). Environ Pollut 173:5-10. https://doi.org/10.1016/j.envpol.2012.09.024

47. Schuler LJ, Hoang TC, Rand GM (2008) Aquatic risk assessment of copper in freshwater and saltwater ecosystems of South Florida. Ecotoxicology 17(7): 642-659. https://doi.org/10.1007/s10646-008-0236-7 
48. Shahid N, Liess M, Knillmann S (2019) Environmental stress increases synergistic effects of pesticide mixtures on Daphnia magna. Environ Sci Technol 53:12586-12593. https://doi.org/10.1021/acs.est.9b04293

49. Snell TW, Johnston RK, Matthews AB, Park N, Berry S, Brashear J. 2019. Using Proales similis (Rotifera) for toxicity assessment in marine waters. Environ Toxicol 34:634-644. https://doi.org/10.1002/tox.22729

50. Snell TW, Marcial HS (2017) Using rotifers to diagnosis the ecological impacts of toxicants. pp. 129147. https://doi.org/10.1007/978-981-10-5635-2_9

51. Taylor WRJ, White NJ (2004) Antimalarial drug toxicity. Drug Saf 27(1): 25-61. https://doi.org/10.2165/00002018-200427010-00003

52. Varano V, Fabbri E, Pasteris A (2017) Assessing the environmental hazard of individual and combined pharmaceuticals: acute and chronic toxicity of fluoxetine and propranolol in the crustacean Daphnia magna. Ecotoxicology 26(6):711-728. https://doi.org/10.1007/s10646-017$1803-6$

53. Vazquez GF, Sharma VK, Magallanes VR, Marmolejo AJ. 1999. Heavy metals in a coastal lagoon of the Gulf of Mexico. Mar Pollut Bull 38:479-485. https://doi.org/10.1016/S0025-326X(98)00173-8

54. Walker CH, Sibly RM, Hopkin SP, Peakall DB (2012) Principles of ecotoxicology. CRC press.

55. Watanabe H, Tamura I, Abe R, Takanobu H, Nakamura A, Suzuki T, Hirose A, Nishimura T, Tatarazako $N$ (2016) Chronic toxicity of an environmentally relevant mixture of pharmaceuticals to three aquatic organisms (alga, daphnid, and fish). EnvironToxicol Chem 35:996-1006. https://doi.org/10.1002/etc.3285

56. Wells MJM, Bell KY, Traexler KA, Pellegrin ML, Morse A (2010) Emerging Pollutants. Water Environ Res 82:2095-2170. https://doi.org/10.2175/106143010X12756668802292

57. World Health Organization 2020. WHO updates clinical care guidance with corticosteroid recommendations. https://www.who.int/news-room/feature-stories /detail/who-updates-clinicalcare-guidance-with-corticosteroid-recommendations.

58. Yan Y, Zou Z, Sun Y, Li X, Xu KF, Wei Y, Jin N, Jiang C (2013) Anti-malaria drug chloroquine is highly effective in treating avian influenza A H5N1 virus infection in an animal model. Cell Res 23:300-302. https://doi.org/10.1038/cr.2012.165

59. Zenker A, Cicero, MR, Prestinaci F, Bottoni P, Carere M (2014) Bioaccumulation and biomagnification potential of pharmaceuticals with a focus to the aquatic environment. J Environ Manage 133:378387. https://doi.org/10.1016/j.jenvman.2013.12.017

60. Zurita JL, Jos Á, Peso A del Salguero M, López-Artíguez M, Repetto G (2005) Ecotoxicological evaluation of the antimalarial drug chloroquine. Aquat Toxicol 75:97-107. https://doi.org/10.1016/j.aquatox.2005.07.009

\section{Tables}


Table 1. Nominal concentrations ( $\mu \mathrm{g} \mathrm{L}^{-1}$ ) of chloroquine (CQ) and copper ( $\mathrm{Cu}$ ) according to the different application factors (AF). Five combinations of CQ and Cu based on the different $\mathrm{AF}$ are shown.

\begin{tabular}{llcc}
\hline \multirow{2}{*}{ Treatment } & \multirow{2}{*}{$\mathrm{AF}(\mathrm{CQ}+\mathrm{Cu})$} & \multicolumn{2}{c}{ Concentration $(\mu \mathrm{g} / \mathrm{L})$} \\
\cline { 3 - 4 } M1 & $0.05+0.05$ & 213 & $\mathrm{Cu}$ \\
\hline & $0.1+0.1$ & 425 & 6.8 \\
& $0.3+0.3$ & 1275 & 20 \\
& $0.5+0.5$ & 2125 & 34 \\
M2 & $0.05+0.1$ & 213 & 6.8 \\
& $0.05+0.3$ & 213 & 20 \\
& $0.05+0.5$ & 213 & 34 \\
& & & \\
M3 & $0.1+0.05$ & 425 & 3.5 \\
& $0.1+0.3$ & 425 & 20 \\
& $0.1+0.5$ & 425 & 34 \\
& & & \\
M4 & $0.3+0.05$ & 1275 & 3.5 \\
& $0.3+0.1$ & 1275 & 6.8 \\
& $0.3+0.5$ & 1275 & 34 \\
M5 & & & \\
& $0.5+0.05$ & 2125 & 3.5 \\
& $0.5+0.1$ & 2125 & 6.8 \\
& $0.5+0.3$ & 2125 & 20 \\
\hline
\end{tabular}

Table 2. Effects of CQ-Cu mixtures on the growth rates of Proales similis at different application factors (AF) for each mixture. $<0.8$ indicates synergy, $0.8<>1.2$ additive, $>$ 1.2 antagonism. 


\begin{tabular}{|c|c|c|c|c|}
\hline & & & & \\
\hline $\mathrm{AF}$ & 0.05 & 0.1 & 0.3 & 0.5 \\
\hline 0.05 & 0.74 & 0.75 & 0.20 & -0.71 \\
\hline 0.1 & 0.84 & 0.67 & 0.39 & -0.18 \\
\hline 0.3 & 1.29 & 0.87 & 0.49 & -0.23 \\
\hline 0.5 & 1.05 & 0.82 & 0.20 & -0.71 \\
\hline & & & & \\
\hline $\mathrm{AF}$ & 0.05 & 0.1 & 0.3 & 0.5 \\
\hline 0.05 & 0.68 & 0.64 & 0.59 & 0.50 \\
\hline 0.1 & 0.86 & 0.63 & 0.49 & 0.49 \\
\hline 0.3 & 1.05 & 0.60 & 0.45 & 0.20 \\
\hline 0.5 & -0.33 & -0.64 & -0.48 & -1.58 \\
\hline
\end{tabular}

Figures 

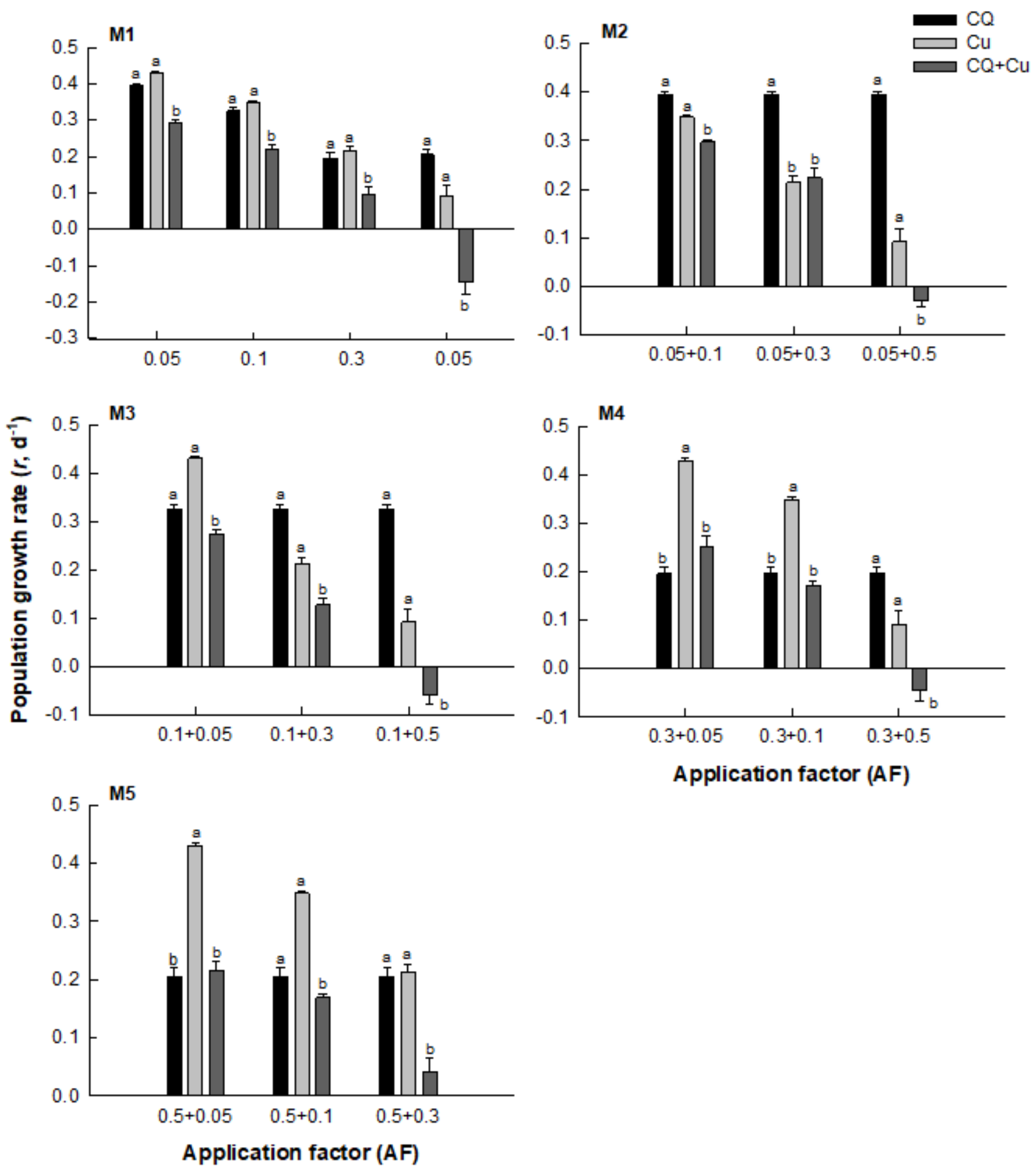

Figure 1

Growth rates of Proales similis exposed at single and mixture (M1 - M5) toxicity of chloroquine (CQ) and copper $(\mathrm{Cu})$ under different application factors $(\mathrm{AF})$. Distinct letters indicate significant $(P<0.05)$ differences among individual chemical toxicity and combined toxicity of $\mathrm{CQ}$ and $\mathrm{Cu}$. 